\title{
Vrangforestillingers historiske innhold
}

Innholdet i vrangforestillinger er preget av den kultur og den tidsperiode pasientene befinner seg i.

Enhver erfaren psykiater vet at vrangforestillingenes innhold endrer seg med skiftende historiske omgivelser. De er gjenstand for historisk pregning. Mens mange pasienter i psykiatriske avdelinger tidligere opplevde å få signaler via radio, er det $\mathrm{i}$ dag ofte trådløs overføring som gjelder. $\mathrm{Og}$ mens det tidligere var relativt suspekt å gå og snakke høyt med seg selv i offentligheten, lurer vi i dag bare på hvor vedkommende har gjemt headsetet.

Det er lite som tyder på at vrangforestillinger er uavhengige av den tid eller den kontekst de oppstår innenfor. I den store litteraturen over psykiatriens og galskapens historie er det imidlertid få som har forsøkt å se galskapen innenfra (1, s. 144). Jeg skal her gjennom noen eksempler antyde hvordan symptomer forenlig med det vi i dag ville kalle vrangforestillinger, har formet seg historisk i kraft av den sosiale, kulturelle og historiske situasjon de utspilte seg innenfor.

\section{Religion}

En januarsøndag 1703 fikk den 21-årige Ester Jönsdotter fra Skåne i Sverige et gråteanfall under prestens preken. Det markerte begynnelsen på en mangeårig lidelseshistorie. Ester sluttet å spise, fikk så store smerter at hun verken kunne sitte eller stå, og ble liggende på ryggen på en hard trebenk i måned etter måned. Etter ett $\mathrm{og}$ et halvt år viste en engel seg for henne og ba henne holde ut; snart skulle en lysende stjerne komme til henne som et Guds tegn. Stjernen viste seg allerede samme kveld, med et så sterkt skinn at hele rommet ble lyst opp. Etter dette fikk Ester en merkelig lindring av smertene. Hun falt i ekstase og dovnet bort 10-40 ganger i timen. Etterpå var hun som død i noen minutter, før hun sukket, trykket hardt mot nese og øyebryn, og begynte å snakke. Hun sa hun hadde vært i en hvit kirke, fått høre og se morsomme ting og lære vidunderlige gudsord. Når hun fikk komme i den hvite kirken, forsvant alle plager. Hun sa hun var satt til verden som et dobbelt speil - for at menneskene skulle oppdage Guds advarende øyne, men også hans himmelske gavmildhet. Den lysende stjernen, som bare Ester så, bevegde seg hver kveld i rommet. Esters tilfelle påkalte oppmerksomhet, og folk strømmet til for å høre henne tale. Eksperter ble tilkalt for å undersøke henne, og endte med å konstatere at hun var syk (1, s. 150-3).

Hva var Esters hvite kirke og den hvite stjernen som bare hun kunne se? På 1700tallet hadde man en tett sosial struktur der religion var et selvfølgelig sosialt og eksistensielt sentrum. Det gjorde at de fleste symptomer som likner det vi ville kalle vrangforestillinger, ble kanalisert $i$ et religiøst språk, og det ga en spesiell dybde til innholdet $\mathrm{i}$ vrangforestillingene som senere tider mangler.

\section{Seksualitet}

I 1861 ble en 26-årig bondegutt fra Romsdal funnet på sin seng på Gaustad asyl med avrevet skrotum, tyggende på avrevne hudlapper. Begge testikler var bortrevne, og kun en ubetydelig del hud var til overs.

\section{«Når kunnskapsfeltet endres, endres også medisinens eksempelsamling»}

Under sutureringen ropte han «Christus vandt med Ære; Hans Navn velsignet være!». Noen dager etter forklarte han at han hadde hørt barnestemmer fra taket som befalte ham å gjøre det. Grunnen var, mente han, at han som barn hadde begått «crimen bestialitatis» på kyrne i fjøset, og senere selv hadde bedrevet onani i utstrakt grad. Han hadde ikke hatt noe redskap å hjelpe seg med, og revet skrotum av med sine egne hender. Testiklene hadde han spist opp (2).

1800-tallet er kalt seksualitetens århundre. Dette århundret ble, som ingen periode tidligere, dominert av troen på at seksualiteten utgjorde den individuelle identitetens mest grunnleggende kjerne, og påvirket både individets politiske og sosiale stilling og dets frihet. Søkelyset på seksualitet frembrakte en rekke nye diagnostiske kategorier: perverse, onanister, homoseksuelle, sodomister, hysterikere, nymfomane, bestiale, zoophile - alle trådte de frem som tydelig klassifiserte seksuelle arter med en egen indre «hemmelighet» som det var opp til den nye vitenskap å avdekke. Onani, eller den ensomme synd som den også ble kalt, oppsto som en veritabel epidemi, særlig blant barn. Mange bekymret seg over barnets seksualitet: lærere, leger, foreldre. Alle skulle lete etter spor av seksuelle forstyrrelser og perversjoner (3). I denne konteksten er det altså at 26-åringen hørte stemmer som sa at han skulle rive av seg testiklene. Det er neppe tilfeldig.

\section{Urbanisering}

Et annet trekk ved 1800-tallet er urbaniseringen. Stadig flere flyttet inn til byene og dyrene inngikk ikke lenger i den utvidede husstand. 11.10. 1857 ble distriktslege Otto Lund (1811-91) bedt om å tilse en kone, BM, 54 år gammel. Han kjente henne som en stillferdig dame, som grundig og pliktoppfyllende gjorde det hun ble bedt om. Hun hadde i flere år lidd av en trykkende smerte i venstre bryst, langs venstre sternalrand. Doktor Lund fant tegn på bronkitt ved den fysiske undersøkelsen, og ordinerte digitalis og «blodkopper» fortil på venstre bryst. Hun ble mer og mer mismodig, lå stadig til sengs, til tross for at doktoren mente det ikke var nødvendig, og 13. desember fikk doktor Lund beskjed fra mannen om at hun hadde tatt sitt liv nedenfor festningen. Samme dag fikk doktoren besøk av en venninne av avdøde. Hun fortalte at venninnen hadde bedt om å bli obdusert. Pasienten hadde i 17 år vært overbevist om at hun hadde et dyr i kroppen, og hun påsto å føle dyrets bevegelser både $\mathrm{i}$ brystet og oppgjennom halsen til hodet. Hun ble den gang innlagt på Rikshospitalet, men siden hun hadde fått følelsen av at legene lo av henne, hadde hun aldri senere fortalt det til noen. Hun mente hun hadde fått dyret i seg fra en kone fra landet som pleide å bringe henne melk (4).

\section{Den medisinske vitenskap}

Den følgende sykehistorien dreier seg om en 42 år gammel sykepleier som er separert og har tre barn som bor hos slektninger. Pga. innsovningsproblemer har hun inhalert eter omtrent daglig, hun skal ha lært dette i Amerika. Hun ble innlagt på Blakstad med diagnosen nevrasteni. Hun fortalte at hun var blitt utsatt for eksperimenter på Bærum sykehus, tappet for flere liter blod, flådd elektrisk, og det var blitt foretatt viviseksjon på henne. Da hun var døende, ga de henne bedøvende innsprøytninger og fikk henne til å legge seg i en kasse som de sendte på sjøen for å «skaffe liket av veien». De ordnet det slik at det skulle se ut som om hun skulle ha dødd av fremkalt abort. Mange andre er også døde, «det ser ut som menneskeæteri i stor stil» (5).

På 1800-tallet skjer en ekspansjon av medisinsk praksis. Kirurgi, antiseptikk og anestesi gjør medisinen handlingsrettet på en helt annen måte enn før, og den vitenskapelige autoritet styrkes. Medisinen blir en viktig samfunnsbærende disiplin. På begynnelsen av 1900-tallet har det vitenskapelige språket også infiltrert vrangforestillingene, som i dette eksemplet fra 
1920-årene. Kliniske eksperimenter vokser frem i denne perioden, og skapte nok bekymring hos noen. Samtidig berører denne historien mange temaer som var blitt debattert offentlig i samtiden: Viviseksjon var omstridt da man utarbeidet den nye straffeloven (6) og den restriktive abortlovgivningen ble diskutert (7, s. 243).

\section{Parapsykologi}

Harald Schjelderup (1895-1974), som ble Norges første professor i psykologi i 1928, var åpen for telepati og mente det fantes en ekte kjerne av paranormale fenomener. Utforskningen av slike paranormale fenomener var i det hele tatt et trekk ved mellomkrigstiden. Slik ble grensene mellom vitenskap og pseudovitenskap og mellom vitenskap og religion utfordret.

Et eksempel er en 30-årig mannlig student, litt rar og nervøs som barn. Sommeren 1922 mente han seg forfulgt av en hypnotisør, skjøt i mars 1923 mot en person han mente forsøkte å hypnotisere ham, mente at han var gift med prinsesse (8).

\section{Sykdom som kulturelt skapt}

Sykdom og sykdomsopplevelse er ikke uavhengige av den tid og det rom de oppleves innenfor. De erfares og tolkes, gis navn og bindes sammen innenfor et gitt historisk tidsrom og en gitt kultur (9). De er med andre ord kulturelt preget (1, s. 183). I denne kommentaren har jeg forenklet noen sentrale poeng: For det første har jeg tatt utgangspunkt $\mathrm{i}$ at sykehistoriene mer eller mindre uredigert formidler en virkelighet utenfor dem. Men sykehistorier vil alltid være fortolket og formidlet av nedskriveren, som tilhører et bestemt medisinsk kunnskapsfelt i en gitt periode. Når kunnskapsfeltet endres, endres også medisinens eksempelsamling. For det andre: Innen dette kunnskapsfeltet velges sykehistorier ut fordi de enten viser trekk som er typiske, eller fordi de avviker betydelig fra den aksepterte standard (10). Noen av sykehistoriene referert over hører nok mest til den andre kategorien, men hva man vil oppfatte som akseptert standard vil også variere. Begge er de imidlertid med på å bygge opp medisinens eksempelsamling, og er derved del av den historiske kontekst de er blitt til innenfor. Argumentet mitt, som bør etterprøves med mer historisk forskning, er det følgende: Antakelig er det vi i dag ville kalle vrangforestillinger mer enn andre symptomer gjenstand for historisk endring også i sitt innhold. Derfor er ikke en vrangforestillingsdiagnose ensbetydende med en frikobling av kultur, politikk og moral. I dobbelt forstand er den preget av sin samtid: I kraft av de symptomer den beretter om, og i kraft av det fagmiljø som har valgt ut og fortolket noen symptomer som sentrale. En slik diagnose frikobler kanskje individuell skyld, men det gjør ikke spørsmålet om samfunnets ansvar mindre relevant. Vi kan ha noe å lære av «Ufornuftens logikk» også (1, s. 10).

\section{Anne Kveim Lie}

a.h.k.lie@medisin.uio.no

Institutt for helse og samfunn

Universitetet i Oslo

Anne Kveim Lie (f. 1969) er førsteamanuensis i medisinsk historie og medisinsk redaktør i Tidsskriftet.

Forfatter har fylt ut ICMJE-skjemaet og oppgir ingen interessekonflikter.
Jeg takker Klara Furuberg for hjelp med innsamling av materiale.

Litteratur

1. Johannisson K. Kroppens tunna skal. Sex essäer om kropp, historia och kultur. Stockholm: Norstedts, 1998.

2. Sandberg ORA. Tilfælde af Sindsygdom. Norsk Mag Lægevidensk, 2. Række 1862; 16: 63-5.

3. Foucault M. Seksualitetes historie I. Viljen til viten. Oslo: Exil forlag, 2001

4. Lund O. Tilfælde af Sindsygdom med fast Vrangforestilling. Norsk Mag Lægevidensk, 2. Række 1859; 13: 310-3.

5. Kasa K. Et tilfælde av polyneuritisk psykose efter kronisk ætermisbruk. Tidsskr Nor Lægeforen 1926; 46: 172-4.

6. Asdal K. Subjected to parliament: the laboratory of experimental medicine and the animal body. Soc Stud Sci 2008; 38: 899-917.

7. Schiøtz A. Det offentlige helsevesen i Norge 1603-2003. Bd. 2. Folkets helse - landets styrke 1850-2003. Oslo: Universitetsforlaget, 2003.

8. Gjessing A. Somnifenbehandling ved psykoser. Tidsskr Nor Lægeforen 1927; 47: 763-4.

9. Aaslestad P. Pasienten som tekst. Fortellerrollen i psykiatriske sykejournaler. Oslo: Tano Aschehoug, 1997

10. Crozier I. Pillow talk: credibility, trust and the sexological case history. Hist Sci 2008; 46: $375-405$

Mottatt 13.3. 2012, første versjon innsendt 19.3. 2012, godkjent 20.3. 2012. Medisinsk redaktør Erlend Hem. 